\title{
THE EFFECT OF SULFADIAZINE, ANTITOXINS, GLOBULINS, AND DOG PLASMA ON DOGS IN TRAUMATIC SHOCK UNDER SODIUM PENTOBARBITAL ANESTHESIA ${ }^{1}$
}

\author{
By RENATO A. RICCA, K. FINK, AND STAFFORD L. WARREN \\ (From the Department of Radiology of the University of Rochester School of Medicine and Dentistry, \\ Rochester, $N . Y$.)
}

(Received for publication June 5, 1944)

\section{INTRODUCTION}

With the awakened interest in shock which came with the Second World War, special problems arose because of new therapeutic agents which have come into use since the First World War. Thus, due to the conditions of modern warfare, wounds which require the use of sulfonamides frequently either co-exist with or are directly related to the development of a shock state. Anesthesia of ten must be used for surgical procedures. For this reason, it is essential to know whether sulfonamides can be employed safely in the presence of traumatic shock and an anesthetic agent. Other workers (1) have investigated the problem in dogs in which shock had been produced by intestinal trauma. They employed sulfanilamide and either pentothal sodium or ether anesthesia. Their conclusion was that therapeutically effective concentrations of sulfanilamide in the blood did not increase the hazard of anesthesia in the presence of traumatic shock. They also concluded that "the evidence was strongly suggestive that sulfanilamide may have been of benefit."

When we first employed sulfadiazine, in experimentally produced traumatic shock under Nembutal anesthesia, in order to control infections of the traumatized thighs (chiefly with the gas producer, $\mathrm{Cl}$. welchii), it was our general impression that sulfadiazine was of direct therapeutic benefit to the dog in shock. The duration of shock was apparently shortened and the animals did not seem to go into very profound shock.

\footnotetext{
1 The work described in this paper was done under a contract, recommended by the Committee on Medical Research, between the Office of Scientific Research and Development and the University of Rochester School of Medicine and Dentistry. Part of the work was also assisted by grants in aid from the Rockefeller Foundation and the Fluid Research Fund of the University of Rochester.
}

Furthermore, over half of the animals so treated survived for several weeks until they were sacrificed. Upon further investigation of this problem, it was discovered that the seemingly beneficial effects of sulfadiazine were the result of lowered environmental temperature (below $28^{\circ}$ C.). This is reported in detail in another paper in this series (2). We now have sufficient data to conclude that sulfadiazine has no direct therapeutic effect upon traumatic shock in the anesthetized dog (Nembutal).

\section{METHODS}

A standardized method of producing shock under sodium pentobarbital anesthesia as a result of a crushing injury was employed throughout these experiments (2). Briefly, it consists of the confinement of one hind extremity of a dog in a press for 5 hours. Following the removal of the press, the animals show various degrees of shock. For consistent and reproducible results, the over-all pressure (2000 pounds) exerted on the soft tissues of the limb and the environmental temperature must be controlled $\left(28^{\circ} \mathrm{C}\right.$. or above). Sodium pentobarbital was administered intraperitoneally in all experiments. The initial dosage was $60 \mathrm{mgm}$., plus $30 \mathrm{mgm}$. per $\mathrm{kgm}$. of body weight. Additional anesthesia was given as required, and in no case was anesthetic administered during the last hour the press was on, and subsequent to removal of the press.

Sulfadiazine levels on whole blood were done as described by Bratton and Marshall (3). The sulfadiazine was administered intravenously as the sodium salt just before releasing the press. Subsequent to removal of the press, it was given every 4 hours, orally if the condition of the dog permitted, or intravenously if not. The amounts given were those required to bring the blood level up to $10 \mathrm{mgm}$. per cent and to maintain it at $10 \mathrm{mgm}$. per cent. In all other respects, the animals were handled exactly like the control dogs, the procedure for which has been reported (2).

In several of the animals, sodium sulfadiazine was given orally for 2 days before the dogs were used in the experiments. The amounts given were those sufficient to keep the blood level at $10 \mathrm{mgm}$. per cent until the press was applied. There was no detectable difference in the be- 
havior of these dogs as compared to those in which the sulfadiazine was first started at removal of the press.

The antitoxins, concentrated plasma, and horse globulin were injected intravenously in various increments, usually starting just before the press was removed, a half an hour later, and then at 2-hour intervals for 8 hours.

\section{RESULTS AND DISCUSSION}

Table I summarizes the results. There was no significant difference in survival rates at the various room temperatures between those dogs which received sulfadiazine and those which did not receive any. Furthermore, there is no significant difference in the survival times of the two groups at different room temperatures. The

TABLE I

Suroival of dogs with crush injury under various treatments

Two thousand pounds over-all pressure was applied on one hind limb for five hours

Veterinary Nembutal anesthesia was given intraperitoneally. There is no detectable influence of sulfadiazine on either survival rates or survival times.

\begin{tabular}{|c|c|c|c|c|c|}
\hline $\begin{array}{c}\text { Room } \\
\text { tem- } \\
\text { perature }\end{array}$ & Treatment & $\begin{array}{l}\text { Num- } \\
\text { ber of } \\
\text { dogs }\end{array}$ & $\begin{array}{c}\text { Num- } \\
\text { ber- } \\
\text { sur- } \\
\text { viving }\end{array}$ & $\begin{array}{l}\text { Sur- } \\
\text { vival }\end{array}$ & $\begin{array}{l}\text { Aver- } \\
\text { age } \\
\text { death } \\
\text { time }\end{array}$ \\
\hline $20^{\circ} \mathrm{C}$. & $\begin{array}{l}\text { Controls } \\
\text { Sulfadiazine } \\
\text { Clostridium anti- } \\
\text { toxin therapeu- } \\
\text { tically } \\
\text { Concentrated } \\
\text { plasma }\end{array}$ & $\begin{array}{l}7 \\
7 \\
9\end{array}$ & $\begin{array}{l}6 \\
7 \\
7 \\
\\
7\end{array}$ & $\begin{array}{c}\text { per cent } \\
86 \\
100 \\
78 \\
\\
78\end{array}$ & $\begin{array}{l}\text { hours } \\
11 \\
10 \frac{1}{4} \\
7 \frac{3}{4}\end{array}$ \\
\hline $24^{\circ} \mathrm{C}$. & $\begin{array}{l}\text { Controls } \\
\text { Sulfadiazine }\end{array}$ & $\begin{array}{r}13 \\
6\end{array}$ & $\begin{array}{l}5 \\
3\end{array}$ & $\begin{array}{l}38 \\
50\end{array}$ & $\begin{array}{l}9 \\
8 \frac{1}{4}\end{array}$ \\
\hline $28^{\circ} \mathrm{C}$. & $\begin{array}{l}\text { Controls } \\
\text { Sulfadiazine } \\
\text { Globulin }\end{array}$ & $\begin{array}{r}20 \\
6 \\
11\end{array}$ & $\begin{array}{l}2 \\
0 \\
5\end{array}$ & $\begin{array}{r}10 \\
0 \\
45\end{array}$ & $\begin{array}{c}7 \frac{3}{4} \\
5 \\
14 \frac{1}{2}\end{array}$ \\
\hline
\end{tabular}

incidence of gas formation by $\mathrm{Cl}$. welchii in the traumatized limb when sulfadiazine was given was reduced to negligible proportions, even when high environmental temperatures were used, and it was thought that the toxins for the $\mathrm{Cl}$. welchii contributed to some extent to the shock syndrome and perhaps shortened the survival time. From the results, however, it appears that the presence or absence of gas in the traumatized leg did not change the course of the experiment. Cl. welchii are readily cultured from normal dog muscle and were identified at autopsy in the crushed tissues by culture ( 5 animals) or by typical gas formation and odor in the majority of the rest of the untreated control experiments performed at a high environmental temperature $\left(28^{\circ} \mathrm{C}\right.$.). Since some of the animals receiving sulfadiazine did well clinically for the period following removal of the press up to a short time before fatal shock suddenly developed and terminated the experiment, it was suggested that the sulfadiazine had a delaying or protective effect either upon the bacterial toxins or the shock state. This was most evident in the experimental group at the environmental temperatures of $24^{\circ} \mathrm{C}$., but is not borne out in the other groups. Several experiments were done in which the effects of sulfadiazine upon the shock produced with intravenous administration of Witte's peptone were investigated. The drug was injected before and after the administration of the peptone. The sulfadiazine apparently had neither protective nor neutralizing power.

The early experiments with sulfadiazine were performed in January when the laboratory was moved to new quarters at a room temperature of $20^{\circ} \mathrm{C}$. All 7 of the dogs given sulfadiazine at this temperature survived. At that time, parallel control experiments were not being run and the influential effect of environmental temperature was not realized. At that time it was felt that sulfadiazine had a direct therapeutic effect in traumatic shock in the dog. Clostridium antitoxin was then tested as a therapeutic agent in traumatic shock to study further the effect of inhibiting the gas gangrene infection on the shock syndrome. The antitoxin was given intravenously in various increments, usually starting just before the removal of the press in order to have available in the blood stream enough neutralizing bodies to protect the animal against toxins absorbed from the traumatized limb. Seven of the 9 dogs given the Clostridium antitoxin therapeutically, survived (Table I). This, at the time, seemed to indicate that if the gas gangrene infection were controlled by sulfadiazine or by specific antitoxins, the fatal shock syndrome might be prevented. Clostridium antitoxin is apparently pure globulin, and the quantity of antitoxin administered contained 18 grams of protein. A series of 9 dogs was then given threefold concentrated plasma equivalent in protein content and volume to that given the Clostridium antitoxin experiments. Seven of the 
9 dogs survived. A series of control experiments was then run, and much to our surprise, 6 of the 7 control dogs survived. The temperature of the room was then raised from $20^{\circ} \mathrm{C}$. to $28^{\circ} \mathrm{C}$. $\left(28^{\circ} \mathrm{C}\right.$. was the temperature in our previous quarters) and the series of controls at the higher temperature died with the usual promptness.

A systematic study of the effect of environmental temperature on traumatic shock was then begun. Since the controls survived at $20^{\circ} \mathrm{C}$., we could not come to any conclusions on the effect of the therapeutic agents (Clostridium antitoxin, concentrated plasma, or sulfadiazine) on shock at that temperature. Sulfadiazine was given at $24^{\circ} \mathrm{C}$. and $28^{\circ} \mathrm{C}$. and it did not seem to be beneficial. Eighteen grams of horse globulin were given to a series of 11 dogs at an environmental temperature of $28^{\circ} \mathrm{C}$. where only 10 per cent of the controls survived, and 5 (45 per cent) of the globulin-treated dogs survived. These limited data suggest that some beneficial effect results from the intravenous administration of horse globulin.

Time did not permit studying the effect of the administration of antitoxins and plasma at a room temperature of $28^{\circ} \mathrm{C}$. It is hoped that these experiments will be performed in other laboratories. We wish to emphasize the importance of running control experiments parallel with therapeutic experiments, instead of doing a large group of control experiments and then turning to therapeutic studies alone. We also wish to emphasize that therapeutic agents should be administered at an environmental temperature of $28^{\circ} \mathrm{C}$. or above. The beneficial and controlling therapeutic effects of low room temperature in traumatic shock may have led others astray in their therapeutic experiments. We plead guilty to similar beneficial findings and conclusions from all of our therapeutic attempts until controls were run at the same environmental temperature. When this was done, the apparent beneficial effects of sulfadiazine were nullified.

\section{CONCLUSIONS}

(1) The hazard entailed in giving anesthesia during traumatic shock is not increased by therapeutically effective concentrations of sulfadiazine in the blood stream.

(2) We have been unable to detect any beneficial effect of sulfadiazine on traumatic shock, although it does reduce the incidence and amount of gas development from $\mathrm{Cl}$. welchii in the tissues of the traumatized site.

(3) The results on the intravenous administration of 18 grams of protein as horse globulin are suggestive that the procedure is beneficial to the clinical course of traumatic shock in dogs under Nembutal anesthesia in an environmental temperature of $28^{\circ} \mathrm{C}$.

(4) Our experiments emphasize the important rôle that environmental temperature may play in experimental traumatic shock, in determining the survival rate of the animal. They suggest that a study of the effect of therapeutic agents such as gas gangrene antitoxins and plasma should be made at high environmental temperatures $\left(28^{\circ} \mathrm{C}\right.$. and above), where the usual survival rate of the traumatized animals is low.

We wish to express our appreciation of the cooperation of the Lederle Company in making available to us the mixed "gas gangrene" antitoxins and the horse globulin used in these experiments, to Dr. R. G. Cutler for the experiments with Witte's peptone, and to the technical group who helped make this work possible: George Casarett, Marion Wesley, Betty Mulryan, John Thomas, Marlene Falkenheim, Jerry Biondi, Edward Mulligan, and Elizabeth Vittum.

\section{BIBLIOGRAPHY}

1. Pender, J. W., Ashburn, F. S., and Essex, H. E., The influence of sulfanilamide on the syndrome of traumatic shock under pentothal sodium and under ether anesthesia. Proc. Staff Meet., Mayo Clin., 1943, 18, 27.

2. Ricca, R. A., Fink, K., Katzin, L. I., and Warren, S. L., Effect of environmental temperature on experimental traumatic shock in dogs. J. Clin. Invest., 1945, 24, 127.

3. Bratton, A. C., and Marshall, E. K., Jr., A new coupling component for sulfanilamide determination. J. Biol. Chem., 1939, 128, 537. 